\title{
MODEL PEMBELAJARAN COOPERATIVE INTEGRATED READING AND COMPOSITION (CIRC) UNTUK PENINGKATAN AKTIVITAS BELAJAR SISWA PADA MATA PELAJARAN GEOGRAFI
}

\author{
Eviliyanto*, Tigor Monang Gultom
}

Pendidikan Geografi IKIP PGRI Pontianak.

\begin{abstract}
This research is aimed to know: 1) the implementation of Cooperative Integrated Reading and Composition (CIRC) model in teaching geography with subject matter "the utilization of natural resources" (UNR); 2) the students' activities in learning geography with CIRC model; and 3) the improvement of the students' activities in learning geography with subject matter "the utilization of natural resources" (UNR) using Cooperative Integrated Reading and Composition (CIRC) model. The research method used is Classroom Action Research (CAR) conducted in two cycles. The subject was the students of class XI Program Social 2 of SMA Negeri 1 Sekadau, Pontianak. The data were collected through direct observation and comparison between the students' percentage scores on learning activities at cycle 1 and those at cycle 2 . The result shows that: 1) the implementation of CIRC model is classified good; 2) the students' learning activities are good: physical activities in cycle 1 are $51.75 \%$, while in cycle 2 are $83.33 \%$; mental activities in cycle 1 are $44.07 \%$, while in cycle 2 are $75.65 \%$; and emotional activities in cycle 1 are 51,66\%, while in cycle 2 are 84,20\%; and 3) CIRC model can improve the students' activities in learning geography.
\end{abstract}

Key words: CIRC model, geography, utilization of natural resources

\begin{abstract}
Abstrak: Tujuan penelitian ini untuk mengetahui: (1) penerapan model cooperative integrated reading and composition (CIRC) pada mata pelajaran geografi materi pemanfaatan sumber daya alam (PSDA); (2) aktivitas belajar siswa pada mata pelajaran geografi materi PSDA dengan model CIRC; dan (3) peningkatan aktivitas belajar siswa pada mata pelajaran geografi materi PSDA melalui penerapan model CIRC. Metode penelitian tindakan kelas (PTK) ini direncanakan dua siklus. Subjek penelitian adalah siswa kelas XI IPS2 SMA Negeri 1 Sekadau, Pontianak. Pengumpulan data dilakukan dengan cara observasi langsung dan membandingkan perolehan nilai persentase aktivitas belajar pada siklus I dan II. Hasil penelitian disimpulkan: (1) Penerapan model pembelajaran CIRC tergolong baik; (2) Aktivitas belajar siswa tergolong aktif (aktivitas fisik siklus I 51,75\% dan siklus II 83,33\%; aktivitas mental siklus I 44,07\% dan siklus II 75,65\%; aktivitas emosional siklus I 51,66\% dan siklus II 84,20\%); dan (3) Model CIRC dapat meningkatan aktivitas belajar siswa dalam belajar geografi
\end{abstract}

Kata kunci: model CIRC, geografi, pemanfaatan sumber daya alam. 


\section{PENDAHULUAN}

Pendidikan merupakan kebutuhan mutlak bagi seluruh umat manusia, tanpa pendidikan mustahil suatu kelompok manusia dapat hidup berkembang sejalan dengan aspirasi untuk maju, sejahtera dan bahagia menurut konsep pandangan hidup mereka. Untuk meningkatkan mutu pendidikan, tentu tidak terlepas bagaimana peran guru dalam pelaksanaan pembelajaran di sekolah. Peran guru dalam menentukan pola kegiatan belajar mengajar di kelas bukan hanya ditentukan oleh apa yang akan dipelajari saja, melainkan juga bagaimana memperkaya pengalaman aktivitas belajar siswa khususnya dalam bidang keilmuan geografi.

Pembelajaran geografi pada jenjang Sekolah Menengah Atas (SMA) bertujuan untuk menumbuh kembangkan pengetahuan, keterampilan dan sikap terhadap fenomena geografi dalam konteks sosial, lingkungan dan kompleks wilayah serta menumbuhkan kesadaran terhadap lingkungan hidup. Akan tetapi, faktanya siswa kurang tertarik dan antusias dalam mengikuti proses pembelajaran geografi. Siswa berasumsi bahwa geografi merupakan mata pelajaran hafalan yang membosankan dan tidak terlalu penting.
Ditinjau dari segi aktivitas belajar siswa (fisik, mental dan emosional) kelas XI IPS 2 dari hasil observasi, masing-masing hanya mencapai $45.50 \%, 44.30 \%$, dan $46.78 \%$. Hal itu terjadi karena komunikasi antara guru dan siswa dalam proses pembelajaran tidak berjalan secara masimal.

Menurut Sanjaya (2006: 101) aktivitas siswa tidak hanya ditentukan oleh aktivitas fisik semata, tetapi juga ditentukan aktivitas non fisik seperti mental, intelektual, dan emosional. Oleh karena itu, aktif dan tidak aktifnya siswa. Hanya siswa sendiri yang tahu secara pasti. Siswa yang diam mendengarkan penjelasan bukan berarti tidak aktif, sebaliknya siswa yang secara fisik aktif memiliki kadar aktivitas yang tinggi pula. Aktivitas siswa merupakan segala kegiatan di kelas pada proses pembelajaran berlangsung yang menghasilkan suatu perilaku, sehingga mempengaruhi hasil belajar. Dengan kata lain siswa dituntut untuk aktif dalam memahami materi pembelajaran, aktif membaca ketika diberi kesempatan untuk membaca, aktif mengacungkan tangan saat guru memberi pertanyaan, aktif memberikan pendapat ketika diberi kesempatan mengeluarkan pendapat, dan aktif bertanya 
ketika diberikan kesempatan untuk bertanya.

Aktivitas siswa dalam pembelajaran geografi tidak terlepas dari bagaimana cara dan strategi guru untuk melibatkan siswanya dalam kelas, dengan demikian metode dalam rangkaian sistem pembelajaran memegang peranan penting. Keberhasilan implementasi strategi pembelajaran tergantung pada cara guru menggunakan metode pembelajaran, karena strategi pembelajaran hanya mungkin dapat diimplementasi melalui penggunaan metode pembelajaran. Jika metode maupun strategi tersebut sesuai dengan materi yang diajarkan, maka aktivitas belajar siswa lebih meningkat, mampu menguasi materi yang diajarkan, dan apabila dilakukan evaluasi, maka siswa dapat mengerjakan soal-soal yang diberikan dengan baik.

Proses pembelajaran sebagai alternatif tindakan yang akan dilakukan guru dengan penerapan model Cooperative Integrated Reading and Composition (CIRC). Menurut Huda (2013: 221) dalam pembelajaran CIRC, setiap siswa bertanggung jawab terhadap tugas kelompok. Setiap anggota kelompok saling mengeluarkan ide-ide untuk me- mahami suatu konsep dan menyelesaikan tugas, sehingga terbentuk pemahaman dan pengalaman belajar yang lama. CIRC secara umum dapat meningkatkan kinerja siswa dalam tugas-tugas akademik, unggul dalam membantu siswa memahami konsepkonsep sulit dan mendorong siswa menumbuhkan kemampuan berpikir kritis. Hal tersebut sesuai dengan ungkapan Jasmine dalam Mudawati (2008:24) yang menyimpulkan "pembelajaran kooperatif model CIRC secara aktif melibatkan kecerdasan interpersonal, mengajar siswa untuk dapat bekerjasama yang baik dengan orang lain, mendorong kolaborasi (kerja sama), berkompromi dan bermusyawarah mencapai kesepakatan dan secara umum menyiapkan mereka untuk masuk dalam dunia hubungan personal”.

Menurut Slavin (2008: 203) dalam model pembelajaran CIRC, siswa ditempatkan dalam kelompok-kelompok kecil yang heterogen terdiri atas 4 atau 5 siswa. Di kelompok ini tidak dibedakan atas jenis kelamin,suku bangsa atau tingkat kecerdasan siswa. Jadi, dalam kelompok ini sebaiknya ada siswa yang pandi, sedang atau lemh dan masingmasing siswa sebaiknya merasa cocok 
satu sama lain. Dengan pembelajaran kelompok diharapkan para siswa dapat meningkatkan pikiran kritisnya, kreatif dan menumbuhkan rasa sosial tinggi. Tujuan utama dari CIRC yaitu untuk membantu para siswa mempelajari kemampuan memahami bacaan, sehingga siswa dapat membuat penjelasan terhadap prediksi mengenai bagaimana masalah-masalah akan diatasi dan merangkum unsur-unsur dari bacaan. Selain itu, dari segi keilmuan geografi diharapkan dapat menghasilkan keterampilan berpikir secara keruangan (spatial thinking skill) guna menjaga keseimbangan lingkungan khususnya dalam pemanfaatan sumberdaya alam.

\section{METODE PENELITIAN}

Penelitian dilakukan di SMA N 1 Sekadau kelas XI IPS 2 dengan jumlah peserta didik 38 orang yang terdiri dari 18 laki-laki dan 20 perempuan. Metode yang digunakan dalam penelitian adalah penelitian tindakan kelas (classroom action research). Penelitian Tindakan Kelas adalah penelitian tindakan (aciton research) yang dilaksanakan oleh guru di dalam kelas (Ekawarna, 2011: 5). Menurut Arikunto dkk (2012:2), penelitian tindakan kelas merupakan suatu pencermatan terhadap kegiatan belajar berupa sebuah tindakan, yang sengaja dimunculkan dan terjadi dalam sebuah kelas secara bersama. Menurut Kemmis dan Mc Taggart dalam Sukardi (2003: 210) penelitian tindakan adalah cara suatu kelompok atau seseorang dalam mengorganisasi suatu kondisi, sehingga mereka dapat mempelajari pengalaman mereka dan membuat pengalaman mereka dapat diakses oleh orang lain. Bentuk penelitian yang digunakan adalah Penelitian Tindakan Kelas (PTK) Kemmis dan Mc Taggart yang merupakan pengembangan dari konsep dasar yang diperkenalkan Kurt Lewin. Adapun bagan model penelitian tindakan kelas yang dimaksud dapat disajikan pada gambar 1 berikut:

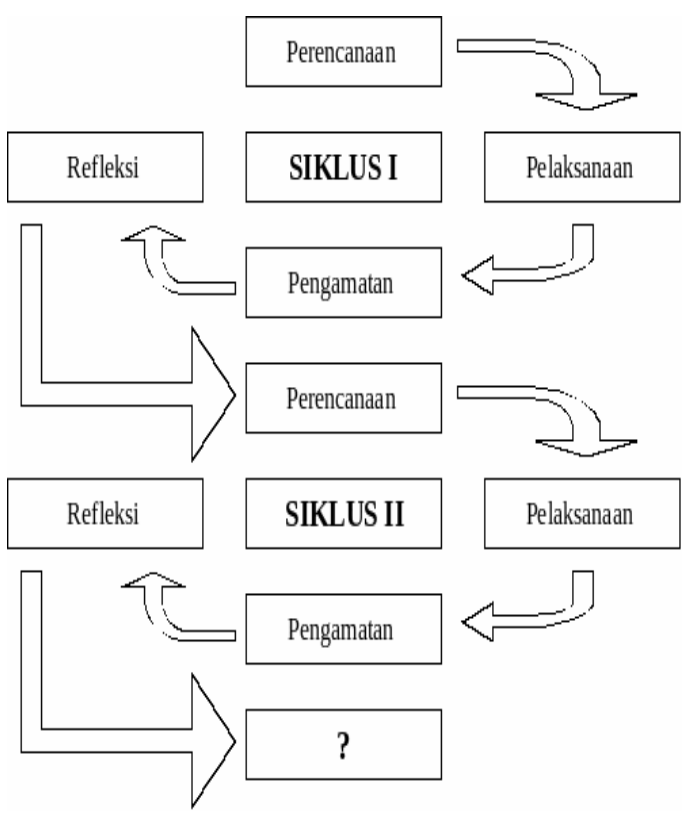

Gambar 1. Penelitian Tindakan Kelas (PTK) Kemmis dan Taggart 
Teknik pengumpulan data yang digunakan dalam penelitian adalah observasi langsung mengenai penerapan model CIRC melaui pengamatan terhadap guru pada materi pemanfaatan sumberdaya alam, sedangkan teknik komunikasi tidak langsung dengan memberikan angket kepada siswa. Analisa penerapan model CIRC dengan menghitung rata-rata aspek yang diamati berdasarkan lembar observasi melalui Alat Penilaian Kinerja Guru (APKG II) yang telah dimodifikasi. Hasil perhitungan rata-rata APKG II mengenai penerapan model CIRC di sesuaikan dengan kriteria yang telah ditentukan. Perhitungan aktivitas belajar siswa dengan menggunakan rumus persentase $(\%)$, selanjutnya disesuaikan dengan kriteria keaktifan seperti pada tabel 1 . berikut:

Tabel 1. Kriteria Aktivitas Belajar

\begin{tabular}{lll}
\multicolumn{2}{c}{ Siswa } & \\
\cline { 1 - 2 } No & Nilai Persentase & \multicolumn{1}{c}{ Keterangan } \\
\hline 1 & $00,01-33,33 \%$ & Rendah \\
2 & $33,34-66,66 \%$ & Sedang \\
3 & $66,67-100 \%$ & Tinggi \\
\hline
\end{tabular}

Popham dalam Yousda \& Arifin (2003: 235)

\section{PEMBAHASAN}

Hasil penelitian berkenaan dengan proses pengumpulan data yang diperoleh dari hasil pengamatan dan komunikasi tidak langsung di lokasi penelitian. Data penelitian yang diperoleh kemudian disajikan dalam rangka untuk menjawab permasalahan yang telah dirumuskan. Data yang dimaksud meliputi: data penerapan model CIRC, aktivitas dan peningkatan aktivitas belajar melalui penerapan model pembelajaran sebagai tindakan perbaikan. Hasil penelitian juga diharapkan mampu memberikan pengatahuan baru mengenai penerapan model CIRC untuk memaksimalkan setiap tahapan pembelajaran yang dilakukan guru khususnya aktivitas siswa/keterlibatan langsung dalam proses belajar. Penerapan model CIRC dalam materi pemanfaatan sumberdaya alam di kelas XI IPS 2 sesuai dengan aspek-aspek yang diamati dapat disajikan pada tabel 2 . berikut:

Tabel 2. Lembar Observasi Penerapan Model CIRC Siklus I

\begin{tabular}{clc}
\hline No & \multicolumn{1}{c}{ Aspek yang Diamati } & Skor \\
\hline 1 & Pra Pembelajaran & 3 \\
2 & Membuka Pembelajaran & 2.5 \\
3 & Kegiatan Inti Pembelajaran & 3.45 \\
4 & Penutup & 2.5 \\
Rata-rata Skor Penerapan Model & 2.86 \\
\multicolumn{2}{c}{ CIRC } \\
Sumber: Analisis Data Primer Melalui \\
APKG II
\end{tabular}

Tabel 2 mendeskripsikan mengenai aspek-aspek yang diamati mengenai penerapan model CIRC yang diterapkan 
guru untuk menjelaskan materi pemanfaatan sumberdaya alam. Total aspek yang diamati berjumlah 20 item terbagi menjadi IV aspek meliputi: I) Pra Pembelajaran, II) Membuka Pelajaran, III) Kegiatan Inti Pembelajaran, dan IV) Penutup. Masing-masing item diberikan skor sesuai dengan langkah-langkah yang telah dilakukan guru pada tiap-tiap siklus. Aspek I berkaitan dengan pembelajaran memperoleh rata-rata skor 3, aspek II 2.5, aspek III 3.45, dan aspek IV 2.5.

Rata-rata kesluruhan aspek yang diamati mengenai penerapan model CIRC pada materi pemanfaatan sumberdaya alam dikelas XI IPS 2 diperoleh skor 2.86. Skor tersebut diperoleh dari hasil pengamatan yang dilakukan oleh kolaborator (peneliti) di kelas XI IPS 2 SMA N 1 Sekadau. Berdasarkan kriteria yang telah ditentukan, rata-rata skor yang diperoleh termasuk dalam kategori cukup. Kriteria yang diperoleh menunjukan bahwa gurumata pelajaran sudah dapat melaksanakanpenerapan model CIRC dalam proses pembelajaran sesuai aspekaspek pada lembar observasi. Hasil perolehan skor rata-rata secara keseluruhan pada siklus I menunjukan bahwa pada aspek I sudah mencapai skor 3, sedangkan aspek II dan IV masih belum dilaksanakan secara maksimal terbukti dari perolehan skor hanya mencapai 2.5 . Selanjutnya aspek III pada kegiatan inti sudah terlaksana dengan baik, artinya guru mampu melaksanakan tahapan model CIRC secara detail. Berdasarkan data yang telah diperoleh pada siklus I, menunjukkan bahwa pelakasanaan pembelajaran yang dilkakukan oleh guru secara keseluruhan belum maksimal, sehingga perlu dilanjutkan pada siklus II.

Penerapan model CIRC digunakan dalam penyampaian materi pemanfaatan sumberdaya alam di kelas XI IPS 2 SMA N 1 Sekadau dalam usaha memperbaiki aktivitas belajar siswa. Harapannya dengan tindakan (penerapan model CIRC) yang akan dilakukan mampu merubah aktivitas siswa menjadi lebih baik karena model tersebut secara langsung menuntu keterlibatan dari siswa. Aktivitas belajar siswa siklus I melalui penerapan model CIRC dapat disajikan pada tabel 3 berikut:

Tabel . Aktivitas Belajar Siklus I

\begin{tabular}{clc}
\multicolumn{3}{c}{ Melalui Model CIRC } \\
\hline No & Indikator Kinerja & $\begin{array}{c}\text { Persentase } \\
(\%)\end{array}$ \\
\hline 1 & Aspek Fisik & 48.36 \\
2 & Aspek Mental & 45.61 \\
3 & Aspek Emosional & 50.58 \\
& Rata-rata & 48.18 \\
\hline
\end{tabular}

Sumber: Analisis Data Primer 
Tabel 3. menunjukkan data hasil aktivitas belajar siswa kelas XI IPS 2 SMA N 1 Sekadau secara keseluruhan hanya mencapai $48.18 \%$. Aspek mental memiliki persentase paling rendah dibandingkan dengan yang lain karena kecenderungannya belum ada keberanian siswa untk mengungkapkan ide atau masukan terhadap materi pelajaran. Kondisi tersebut dipengaruhi secara tidak langsung oleh aspek fisik dan emosional siswa karena masih relatif rendah minat untuk membaca, mendengarkan, bertanya bahkan menjawab pertanyaan dari guru mengenai materi yang disampaikan, sehingga secara umum belum mencapai target yang diharapkan. Hal ini sesuai dengan hasil pra observasi yang menunjukkan bahwasannya siswa beranggapan mata pelajaran geografi pada umumnya hanya bersifat hafalan dan cenderung membosankan. Paling tidak hasil siklus I yang dilaksanakan sudah mengalami perubahan dari segi aktivitas belajar siswanya dan minimal aktivitas emosional siswa sebagai kunci untuk merubah cara pandang siswa mengenai mata pelajaran geografi mengalami perubahan. Aktivitas emosional mengacu pada minat dan semangat siswa untuk belajar dalam upaya mendorong pening- katan aktivitas fisik dan mental, walaupun pada dasarnya ketiga aktivitas teersebut saling berkaitan satu dengan lainnya dan bisa dikatakan tidak terpisahkan atau saling mempengaruhi.

Hasil perolehan nilai persentase aktivitas belajar siswa pada siklus I termasuk dalam kategori cukup aktif (48.18\%). Hasil analisis data mengenai aktivitas belajar siswa melalui komunikasi tidak langsung masih belum maksimal dalam setiap tahapan kegiatan pembelajaran. Buktinya masih banyak siswa yang tidak membaca catatan atau buku bahkan mendengarkan mengenai materi pemanfaatan sumberdaya alam yang disampaikan guru melalui model CIRC. Indikasi demikian sudah barang tentu akan berpengaruh terhadap aktivitas mental dan emosional siswa, sehingga proses pembelajaran tidak berjalan sesuai harapan yang telah dirumuskan. Untuk itu, perlu ada tindakan lanjutan yang harus dilakuka pada siklus II dalam usaha meningkatkan aktivitas belajar siswa di kelas XI IPS 2 baik dari segi fisik, mental dan emosional. Secara garis besar permasalahan yang masih muncul pada siklus I dapat direfleksikan sebagai berikut: (1) Perlu persiapan yang lebih baik lagi bagi guru dalam penerapan model CIRC khususnya pada 
tahap pra pembelajaran, membuka pelajaran dan penutup.(2)Sudah ada peningkatan/perubahan aktivitas belajar (fisik, mental, emosional) siswa dibandingkan dengan hasil pra observasi. (3) Aktivitas belajar secara fisik melalui penerapan model CIRC diperoleh persentase sebesar 48.36.(4) Aktivitas belajar secara mental melalui penerapan model CIRC diperoleh persentase sebesar 45.61. (5)Aktivitas belajar secara mental melalui penerapan model CIRC diperoleh persentase se-besar 50.58 .

Hasil refleksi yang sudah dirumuskan pada siklus I dijadikan sebagai dasar untuk melakukan tindakan lanjutan pada siklus II guna memperbaiki setiap tahapan penerapan model CIRC dan aktivitas belajar siswa. Lebih lanjut mengenai hasil penerapan model CIRC pada materi pemanfaatan sumberdaya alam di kelas XI IPS 2 SMA N 1 Sekadau dapat disajikan dalam tabel 4 . berikut:

Tabel 1.4. Lembar Observasi Penerapan Model CIRC Siklus II

\begin{tabular}{clc}
\hline No & Aspek yang Diamati & Skor \\
\hline 1 & Pra Pembelajaran & 3.5 \\
2 & Membuka Pembelajaran & 3 \\
3 & Kegiatan Inti Pembelaja- & 3.65 \\
& ran & \\
4 & Penutup & 3 \\
Rata-rata Skor Penerapan & 3.29 \\
$\quad$ Model CIRC & \\
\hline
\end{tabular}

Sumber: Analisis Data Primer Melalui APKG II

Tabel 4 menunjukkan rata-rata perolehan skor hasil pengamatan terhadap guru melalui penerapan model CIRC pada materi pemanfaatan sumberdaya alam. Pada masing-masing aspek yang diamati menggunakan alat penilaian kinerja guru (APKG II) sudah mengalami peningkatan. Mulai dari tahap pra pembelajaran sampai kegiatan penutup sudah mencapai skor diatas tiga atau termasuk dalam kategori baik. Rata-rata skor secara keseluruhan dari hasil pengamatan yang telah dilakukan sudah mencapai skor 3.29. Seperti halnya yang disajikan dalam tabel 4 aspek kegiatan inti pembelajaran memiliki skor tertinggi sebesar 3.65. Aspek tersebut merupakan inti pelaksanaan model pembelajaran CIRC ditinjau dari segi penguasaan materi sampai tahap evaluasi sudah berjalan secara baik.

Guru sebagai pengontrol kegiatan pembelajaran sudah mampu mengaplikasikan model CIRC sesuai ketentuan atau sintak yang telah direncanakan. Penerapan model CIRC sebagai alternatif tindakan yang dilakukan guru dalam rangka merubah/meningkatkan aktivitas belajar siswa kelas XI IPS 2 SMA N 1 Sekadau. 
Pemilihan model CIRC sebagai tindakan untuk peningkatan aktivitas didasarkan pada asas keterlibatan siswa secara langsung dalam proses pembelajaran. Siswa dituntut lebih aktif dalam setiap tahapan pembelajaran guna memahami materi pemanfaatan sumberdaya alam. Berdasarkan tindakan yang telah dilakukan guru kaitannya dengan penerapan model CIRC di kelas XI IPS 2 pada materi pemanfaatan sumberdaya alam faktanya mampu mengubah situasi pembelajaran. Bentuk komunikasi yang terjadi berlangsung dua arah, guru tidak lagi mendominasi setiap tahapan kegiatan pembelajaran. Perubahan tersebut dipengaruhi oleh penerapan model CIRC yang telah dilaksanakan secara maksimal. Fakta menunjukkan bahwasannya terjadi peningkatan aktivitas belajar siswa baik fisik, mental dan emosional setelah diberikan tindakan berupa penerapan model pembelajaran CIRC. Lebih lanjut mengenai data aktivitas belajar siswa pada siklus II dapat disajikan dalam tabel 5 . berikut:

Tabel 5. Aktivitas Belajar Siklus II

\begin{tabular}{clc}
\multicolumn{3}{c}{ Melalui Model CIRC } \\
\hline No & Indikator Kinerja & $\begin{array}{c}\text { Persentase } \\
(\%)\end{array}$ \\
\hline 1 & Aspek Fisik & 52.41 \\
2 & Aspek Mental & 51.32 \\
3 & Aspek Emosional & 57.60 \\
& Rata-rata & 53.78 \\
\hline
\end{tabular}

Sumber: Analisis Data Primer
Berdasarkan tabel 5. menunjukkan perolehan data mengenai peningkatan aktivitas belajar siswa di kelas XI IPS 2. Skor rata-rata yang diperoleh dari ketiga indikator aktivitas belajar mencapai persentase sebesar 53,78. Menurut kriteria perolehan skor aktivitas belajar termasuk dalam kategori cukup baik. Masing-masing aspek aktivitas sudah memperlihatkan perubahan yang terjadi selama berlangsungnya kegiatan pembelajaran. Bentuk perubahan yang nampak dari hasil analisa data antara lain: sudah ada kemauan membaca buku, catatan, keberanian bertanya dan menjawab pertanyaan dari guru dan sesama siswa, serta tumbuhnya semangat dan minat belajar mata pelajaran geografi. Perubahan aktivitas sebagian siswa secara tidak langsung memberikan stimulus positif bagi yang lain untuk mengikutinya. Memahami karakteristik siswa yang beragam merupakan pekerjaan rumah bagi seorang guru untuk menciptakan suasana belajar efektif yang mengedepankan keterlibatan peserta didik secara langsung. Oleh sebab itu, melalui tutor sejawat baik itu dari cara belajar, berkomunikasi, menumbuhkan kepercayaan diri dan lain sebagainya akan lebih mudah dicapai daripada mengandalkan sepenuhnya dari guru. 
Semakin besar aktivitas siswa disetiap tahapan pembelajaran berpengaruh terhadap berkurangnya dominasi guru menyampaikan informasi mengenai materi pelajaran.

Secara keseluruhan melalui penerapan model pembelajaran CIRC sesuai rancangan hanya pada siklus II mencapai lebih dari $50 \%$ perolehan persentasenya. Jika dilihat dari segi tujuan yang telah dirumuskan menurut analisis data aktivitas belajar siswa dikelas XI IPS 2 mengalami perkembangan cukup baik. Minimal tiap-tiap aspek aktivitas belajar siswa mengalami perubahan khususnya pada materi pemanfaatan sumberdaya alam. Perlu adanya usaha kreatif dan inovatif guru untuk memilih strategi yang mengutamakan keterlibatan siswa secara optimal. Semakin tinggi aktivitas yang dilakukan siswa dikelas akan menumbuhkan semangat dan minat untuk belajar mengenai informasi atau pengetahuan yang belum diketahui.Mereka dapat menyadari secara utuh arti penting melakukan setiap aktivitas belajar tanpa ada unsur paksaan dari orang lain guna mencapai tujuan yang diharapkan. Jika setiap siswa dapat menumbuhkan keinginan tersebut dapat dipastikan kegiatan pembelajaran dapat berlangsung secara efektif dan efisien sesuai rancangan yang telah disusun. Berdasarkan hasil analisis data yang telah dipaparkan pada siklus I dan II melalui penelitian tindakan kelas menunjukkan adanya peningkatan aktivitas belajar pada materi pemanfaatan sumberdaya alam dikelas XI IPS 2. Indikator peningkatan aktivitas belajar siswa dapat diperlihatkan sebagai berikut(1)Penerapan model CIRC dari data siklus I dan II masing-masing memperoleh rata-rata skor 2,86 dan 3,29. (2)Aktivitas fisik siswa dari data siklus I dan II masingmasing memiliki persentase sebesar 48,36 dan 52,41. (3)Aktivitas mental siswa dari data siklus I dan II masingmasing memiliki persentase sebesar 45,61 dan 51,32. (4)Aktivitas emosional siswa dari data siklus I dan II masingmasing memiliki persentase sebesar 50,58 dan 57,60.

Hasil analisis data yang sudah ditampilkan pada siklus I dan II sebelumnya dapat dikaji lebih lanjut guna dilakukan pembahasan. Secara rinci data yang dimaksud mengenai proses penerapan model CIRC dan data aktivitas belajar siswa di kelas XI IPS 2 SMA N 1 Sekadau. Lebih lanjut mengenai data tersebut dapat disajikan dalam tabel 6 dan 7 berikut: 
Tabel 6. Rekapitulasi Data Penerapan Model CIRC Siklus I dan II

\begin{tabular}{ccccc}
\hline No & Kelas & $\begin{array}{c}\text { Siklus } \\
\text { I }\end{array}$ & $\begin{array}{c}\text { Siklus } \\
\text { II }\end{array}$ & $\begin{array}{c}\text { Skor } \\
\text { Pening- } \\
\text { katan }\end{array}$ \\
\hline 1 & XI IPS 2 & 2.86 & 3.29 & 0,43 \\
\hline
\end{tabular}

Sumber: Analisis Data Primer

Menurut tabel 6. menunjukkan perolehan skor penerapan model CIRC yang dilakukan guru pada materi pemanfaatan sumberdaya alam di kelas XI IPS 2. Mengacu pada tujuan yang dirumuskan sudah adanya perubahan yang dilakukan guru mengenai penerapan model tersebut, meskipun rentangnya relatif tidak besar. Pencapaian selisih skor atau peningkatan disetiap aspek pembelajaran mencerminkan kesadaran guru akan beberapa tahap pembelajaran yang tidak dilakukan. Kreativitas dan inovasi guru mengelola kelas diharapkan dapat menarik respon siswa mengikuti kegiatan pembelajaran. Ditinjau dari segi materi pelajaran geografi yang cukup kompleks sudah barang tentu tidak semuanya dapat disampaikan dengan satu strategi saja. Tiap-tiap materi memiliki kedalaman informasi yang berbedabeda, sehingga diperlukan cara agar siswa lebih mudah menerima pengetahuan tersebut dengan mudah. Selain itu, adakalanya materi pelajaran yang menuntut keaktifan belajar siswa secara optimal dan guru cukup menyampaikan garis besar atau poin penting materi tersebut.

Seorang guru tidak selalu menjadi sumber belajar yang dominan dalam proses pembelajaran dikelas. Apalagi perkembangan ilmu pengetahuan dan teknologi yang cukup pesat seperti sekarang ini, guru hanya perlu menunjukkan kepada siswa mengenai cara memperoleh sumber informasi. Bentuk sumber belajar yang dimaksud bisa diperoleh dari buku dan media internet yang valid. Karena media internet ini cukup luas dan banyak, maka guru wajib mengarahkan kepada siswa sumber/lieteratur mana yang bisa dimanfaatkan atau relevan dengan materi pelajaran.

Semakin tinggi aktivitas belajar siswa dikelas, maka beban seorang guru mengelola kelas menjadi lebih ringan atau paling tidak berkurang. Kondisi demikian, jika terus dipertahankan akan berdampak positif dari segi waktu yang dimiliki guru lebih banyak. Pemanfaatan waktu yang efektif dan efisien bisa digunakan untuk meningkatkan kompetensi guru dibidang pembelajaran. Seperti halnya melakukan kajian penelitian dibidang pendidikan yang hasil akhirnya dapat dimanfaatkan oleh siswa. Terlebih 
lagi kajian pemanfaatan strategi pembelajaran, media dan lain sebagainya dengan sasaran akhir peningkatan kualitas pengelolaan kelas. Dominasi guru disetiap tahapan pembelajaran harus senantiasa diminimalisir dalam rangka meningkatkan aktivitas siswa. Tujuannya untuk membangun dan memun- culkan ide-ide kreatif siswa agar memperoleh informasi atau pengalaman belajar secara mandiri. Jadi, guru hanya memberikan stimulus/rangsangan sedangkan siswa berusaha mengkaji dan bahkan mengembangkan informasi yang diperoleh.

Tabel 7. Rekapitulasi Data Aktivitas Belajar Siklus I dan II

\begin{tabular}{ccccccc}
\hline Kelas & \multicolumn{3}{c}{ Siklus I } & \multicolumn{3}{c}{ Siklus II } \\
\cline { 2 - 7 } XI IPS 2 & Fisik & Mental & Emo sional & Fisik & Mental & Emosional \\
\hline
\end{tabular}

Berdasarkan tabel 7. diketahui bahwasannya aktivitas belajar pada siklus I dan II terjadi peningkatan dimasing-masing aspek (fisik, mental, dan emosional). Total peningkatan aktivitas siswa di kelas XI IPS 2 SMA N 1 Sekadau sudah mencapai lebi dari 50\%. Hasil persentase tersebut belum menunjukkan aktivitas maksimal yang dilakukan siswa. Namun, dilihat dari tujuan yang dirumuskan persentase sudah mengalami peningkatan di tiga aspek (fisik, mental, dan emosional). Bukan pekerjaan mudah bagi seorang guru untuk merubah perilaku siswa dalam kegiatan pembelajaran. Ditambah lagi dengan keragaman karakter siswa yang harus dipahami guru guna menentukan/ memilih strategi yang tepat sesuai penjelasan sebelumnya. Perlu kerjasama yang intensif antara guru dan siswa dalam rangka mencapai kegiatan pembelajaran efektif dan efisien dengan menitikberatkan keterlibatan siswa secara optimal. Hasil analisis data yang ditampilkan pada rekapitulasi aktivitas belajar siklus I dan II perlu tindakan lanjutan. Dasarnya pada tumbuhnya kesadaran guru dan pemberian perlakuan yang sudah mampu meningkatkan aktivitas belajar siswa. Kesadaran yang dimaksud adalah masih ada tahapan yang tidak dijalankan sesuai rancangan/skenario pembelajaran yang disusun di siklus I dan II. Faktor tersebut merupakan modal penting untuk melanjutkan proses pembelajaran pada materi berikutnya guna peningkatan aktivitas belajar siswa. Menurut teori penelitian tindakan kelas sudah menjadi 
keharusan bagi guru untuk menyelesaikan permasalahan yang telah dirumuskan selama kegiatan belajar mengajar.

\section{KESIMPULAN}

1. Penerapan model pembelajaran CIRC pada materi pemanfaatan sumberdaya alam di kelas XI IPS 2 SMA N 1 Sekadau termasuk kategori baik.
2. Aktivitas belajar siswa melalui model pembelajaran CIRC pada materi pemanfaatan sumber daya alam di kelas XI IPS 2 SMA Negeri 1 Sekadau termasuk kategori cukup aktif.

3. Terdapat peningkatan aktivitas belajar siswa dengan penggunaan model pembelajaran CIRC di kelas XI IPS2 SMA Negeri 1 Sekadau pada materi pemanfaatan sumber daya alam.

\section{DAFTAR PUSTAKA}

Arikunto Suharsimi, (2012). Penelitian Tindakan Kelas. Jakarta: PT. Bumi Aksara

Ekawarna, (2011). Penelitian Tindakan Kelas. Jakarta: Gaung Persada.

Huda Miftahul.(2013). Model-Model Pengajaran dan Pembelajaran Isu-Isu Metodis dan Paradigmatis. Yogyakarta: Pustaka Pelajar.

Sanjaya Wina.(2006). Strategi Pembelajaran Berorientasi Standar Proses Pendidikan. Jakarta: Kencana.

Slavin.(2008). Cooperative Learning. Bandung: Nusa Media

Sukardi.(2003). Metodologi Penelitian Pendidikan. Jakarta: PT. Bumi Aksara.

Mudawati, Sri.(2008). Thesis., Peningkatan Aktivitas Belajar Melalui Penerapan Model Pembelajaran Kooperatif Terpadu Membaca dan Menulis (CIRC) pada Pokok Bahasan Lingkungan Hidup dan Pelestariannya di Kelas VIII MTs Negeri Gandusari Blitar. Thesis. Malang: Universitas Negeri Malang.

Yousda Ine I Amirman \& Arifin Zainal,(2003). Penelitian dan Statistik Pendidikan. Jakarta: Bumi Aksara. 